\title{
Evaluation of Propargyl Bromide as a Soil Fumigant
}

\author{
Inga A. Zasada ${ }^{1}$ \\ USDA-ARS Nematology Laboratory, 10300 Baltimore Avenue, Beltsville, \\ $M D 20705$
}

\author{
Clyde L. Elmore \\ Department of Plant Sciences, University of California, One Shields Avenue, \\ Davis, CA 95616
}

\author{
Lani E. Yakabe and James D. MacDonald ${ }^{2}$ \\ Department of Plant Pathology, University of California, One Shields \\ Avenue, Davis, CA 95616
}

Additional index words. solarization, methyl bromide alternatives, soil fumigants, floral crops

\begin{abstract}
The cut flower and bulb industry in California is an important part of the state's agricultural economy and it has relied heavily upon the use of methyl bromide as a treatment to control soil-borne pests. With the phase out of methyl bromide, it is important to develop alternatives that will maintain crop productivity. This report describes research testing the efficacy of propargyl bromide against selected nematode, fungal, and weed species. Three sites were selected in California to represent different soil types and environments. Propargyl bromide was applied to soil in large, buried containers at rates ranging from 28 to $168 \mathrm{~kg} \cdot \mathrm{ha}^{-1}$ and compared with standard soil fumigants. The citrus nematode (Tylenchulus semipenetrans Cobb) and an isolate of Fusarium oxysporum Schlechtend:Fr were both controlled at the lowest rate of propargyl bromide tested: $28 \mathrm{~kg} \cdot \mathrm{ha}^{-1}$. Weed species varied greatly in their sensitivity to propargyl bromide. A $100 \%$ reduction in common purslane (Portulaca oleracea $\mathrm{L}$.) and pigweed (Amaranthus retroflexus L.) germination occurred at $112 \mathrm{~kg} \cdot \mathrm{ha}^{-1}$ propargyl bromide, regardless of geographical location. Results for annual bluegrass (Poa annua L.) control were more variable across locations and years, but more than $90 \%$ control was consistently achieved with $168 \mathrm{~kg} \cdot \mathrm{ha}^{-1}$ propargyl bromide. Cheeseweed (Malva parviflora L.) and field bindweed (Convolvulus arvensis L.) were never consistently controlled by propargyl bromide. When compared with the soil fumigants methyl bromide, iodomethane, and metam sodium, propargyl bromide provided comparable control of all soilborne pests, but at much lower rates. Although higher rates of propargyl bromide, more than $112 \mathrm{~kg} \cdot \mathrm{ha}^{-1}$, were needed to control weeds, these rates still were almost half that required of the other standard fumigants.
\end{abstract}

The California floriculture industry is a large and important component of the state's agricultural economy, with a reported value of about $\$ 1$ billion in 2004 [U.S. Department of Agriculture-National Agricultural Statistics Service (NASS)]. In California, floriculture crops are grown on $\approx 2900$ acres of

\footnotetext{
Received for publication 28 Dec. 2006. Accepted for publication 26 Feb. 2007.

This research was funded by a grant from the U.S. Department of Agriculture.

Mention of trade names or commercial products in this publication is solely for the purpose of providing specific information and does not imply recommendation or endorsement by the U.S. Department of Agriculture.

The authors thank Tom Trout (USDA-ARS, Fresno, CA) for providing the propargyl bromide used in this study and Linda Bolkan and John Roncoroni for technical assistance.

${ }^{1}$ Former Graduate Research Assistant, Department of Plant Pathology, University of California, Davis, CA.

${ }^{2}$ To whom reprint requests should be addressed; e-mail jdmacdonald@ucdavis.edu
}

covered land and 8000 acres of open ground. Cut flowers and bulbs are high-value crops that require large expenditures of capital to establish and bring to commercial maturity. The cut flower and bulb industry has relied heavily upon the use of methyl bromide/ chloropicrin (MBC) as a key soil treatment for crop production. It has been used as a preplant fumigant to control soil-borne fungi, nematodes, bacteria, and weeds, as well as to kill the soil-borne remnants of previous crops (e.g., bulbs) that can sprout and contaminate the next crop.

The ozone depletion potential of methyl bromide has resulted in the phase-out of this chemical except for a few specific uses. Without methyl bromide, or an equally efficacious alternative, cut flower and bulb producers face potentially serious production limitations. It is extremely important that alternatives be developed to manage the pests formerly managed by methyl bromide. However, because of the diversity of the crops represented and the comparatively small acreage involved, the floriculture industry has received inadequate methyl bromide alternative research compared with other crops. Furthermore, although it is too soon to know, there are concerns that floricultural crops will not compete favorably against large-acreage crops for alternate materials like 1,3-dichloropropene, which have "township caps" limiting their use within geographical areas.

Propargyl bromide is one of many compounds being considered as a methyl bromide alternative (Allaire et al., 2005; Ma et al., 2001; Schneider et al., 2006). In 1957, Dow Chemical Company was granted a patent for propargyl bromide as a soil fumigant. However, it subsequently was taken off the market because of unstable handling characteristics. The handling characteristics of propargyl bromide continue to be a challenge for its commercialization. However, its physical properties make it attractive as a soil fumigant because it moves readily through soil, has a short soil degradation time, has strong biocidal properties, and does not have ozonedepleting characteristics (Yates and Gan, 1998). In the midlate 1990 s, it was suggested that propargyl bromide should be revisited as a viable methyl bromide alternative, and the U.S. Department of Agriculture decided to sponsor research that would evaluate the efficacy and environmental fate of the chemical used as a soil fumigant. This research was undertaken as part of the efficacy testing and sought 1) to evaluate propargyl bromide against a diversity of soil-borne pests, 2) to determine propargyl bromide efficacy in three different geographical environments, and 3) to compare propargyl bromide with $\mathrm{MBC}$, iodomethane, and metam sodium.

\section{Materials and Methods}

The handling of soil-borne organisms was identical for all experiments. Soil-containing nematodes, fungal spores, or weed seeds was placed in $3.8 \times 7.6-\mathrm{cm}$ sachets made of 40-mesh nylon cloth. The sachets were sealed closed with hot glue and had a length of colored nylon string attached to denote the intended depth of placement in the plot $(5,15$, or $30 \mathrm{~cm}$ ).

Nematode. Five grams of soil infested with mixed stages of the citrus nematode (Tylenchulus semipenetrans Cobb), collected from an olive orchard in Orland, CA, was placed in each sachet. Extra sachets were prepared for each field trial to quantify the number of nematodes per gram of soil before burial. Sachets were kept at $4{ }^{\circ} \mathrm{C}$ until use, usually within days. When sachets containing nematodes were recovered from field experiments, they were processed within $48 \mathrm{~h}$ of removal from field soil. Live nematodes were extracted by placing the sachets on a mesh support on a Baermann funnel for $72 \mathrm{~h}$ (Ingham, 1994). The total number of citrus nematodes retrieved per sachet was determined.

Fusarium. Inoculum of Fusarium oxysporum Schlechtend:Fr was prepared by streaking spores onto a series of potato dextrose agar plates. The plates were incubated 
at $25{ }^{\circ} \mathrm{C}$ under lights for 5 to $7 \mathrm{~d}$ until the fungus was actively growing and producing abundant spores. Plates were then flooded with sterile, distilled water, rubbed with a glass rod to dislodge spores, and the resulting spore suspension was decanted into a beaker. The concentration of spores in the resulting harvest solution was determined using a hemocytometer. A spore suspension containing $10^{5}$ to $10^{8}$ spores then was poured onto sterile field soil and mixed by hand. This process was repeated several times, after which the soil was allowed to air-dry slowly to promote the formation of chlamydospores as the surviving propagules. After drying, the soil was mixed thoroughly to achieve even distribution of inoculum, and the resulting inoculum level was determined by dilution plating to ensure that $10^{4}$ to $10^{5}$ colony forming units (cfu)/g of soil could be recovered. This stock soil was then stored in a cool, dry, dark place. Before placing soil into sachets for experimental use, several aliquots of the stored, infested soil were suspended in sterile water blanks and then pipetted onto agar media to verify that population levels were holding stable. Five grams of dry infested soil was added to each fungal sachet, and the sachets were prepared as described earlier. Fusarium oxysporum sachets were prepared several weeks before burial in pots and stored at $4{ }^{\circ} \mathrm{C}$ until use.

When sachets containing $F$. oxysporum were recovered from field experiments, they were initially air-dried on a laboratory bench for about 1 week, after which they were cut open with sterile scissors and the soil was placed in a plastic weigh boat in which any small clods were broken up using a surfacesterilized pestle. The dry, pulverized soil was then stored in a sealed, labeled glass vial at room temperature until assayed for viable propagules. Assays consisted of preparing serial dilutions that were then spread onto Petri dishes containing Komada's medium (Komada, 1975). Each soil solution was spread onto three series of plates. Plates were incubated at $25{ }^{\circ} \mathrm{C}$ under lights, and fungal colonies were counted at 3 and $6 \mathrm{~d}$ of incubation. The total number of Fusarium colonies that resulted was counted to provide an estimate of propagule survival.

Weeds. Seeds of field bindweed (Convolvulus arvensis L.), redroot pigweed (Amaranthus retroflexus L.), common purslane (Portulaca oleracea L.), annual bluegrass (Poa annua L.) and cheeseweed (Malva parviflora L.) (Valley Seed Co., Fresno, CA) were treated in a similar manner. Three samples of 100 seeds of each species were weighed to determine a mean weight per 100 seeds. Then, 100 seeds (by weight) of each species were placed individually into sachets, and were sealed and tagged as described earlier. When sachets containing weed seeds were removed from the field, they were cut open and the seeds were placed on a single sheet of moistened filter paper in a $100 \times$ $15-\mathrm{mm}$ plastic Petri dish. The filter paper was remoistened over time as needed. Dishes containing redroot pigweed, field bindweed, and common purslane were incubated at room temperature. Petri dishes containing annual bluegrass and cheeseweed were placed in a germinator at $30{ }^{\circ} \mathrm{C}$ and set to provide $8 \mathrm{~h} / 16 \mathrm{~h}$ day/night lighting. Germinated seeds were counted and removed over a 2-week period. If the radicle was present, a seed was considered germinated. After 2 weeks, the ungerminated seeds were tested to determine their viability. Representative samples for each species were cut and treated with a $0.25 \%$ tetrazolium solution for $12 \mathrm{~h}$. Seeds were then examined to determine whether staining occurred, indicating viability. This result also was compared with a squeeze test during which slight pressure was applied to seeds with tweezers. If a seed was hard, it was counted as viable; if soft, it was considered dead. These two methods were found to be comparable for field bindweed and cheeseweed.

Container experiments. Field experiments were done during 2000 and 2001 at three locations in California representing a range of climates and soil types. The soils were a Yolo loam (Davis, CA), 1.08\% organic matter (OM), $42 \%$ sand, $40 \%$ silt, $18 \%$ clay; Elder sandy loam [Monterey Bay Academy (MBA), CA], 0.98\% OM, 64\% sand, 21\% silt, $15 \%$ clay; and Watsonville silt loam (Watsonville, CA), 2.6\% OM, 17\% sand, $59 \%$ silt, $24 \%$ clay

The experiments were carried out in large plastic pots $(75 \mathrm{~L})$ buried in the fields so that different fumigants could be tested in small plots without concern of lateral diffusion confounding the results of adjoining replicates (Fig. 1). The pots were installed by setting them into trenches cut in the soil with a backhoe. The pots were then placed in the trenches and the trenches backfilled around the pots, leaving $\approx 8 \mathrm{~cm}$ of the pot rim extended above the soil grade. After back- filling, soil was hand packed into the bottoms of the pots to form a layer $30 \mathrm{~cm}$ below soil grade. At this point, one set of sachets including citrus nematode, $F$. oxysporum, and each of the weed species was set in the pot on the surface of the packed soil, with labeled strings extending upward out of the pots. The sachets were then covered with more soil that again was added and packed until the level in the pots was $15 \mathrm{~cm}$ below grade. At this point, another set of sachets was laid in place, with strings and tags extending up out of the pot. More soil was then added and packed to bring the surface to $5 \mathrm{~cm}$ below grade, where the last layer of sachets was installed. These were capped with a final layer of soil that brought the soil in the pot up to the external grade level. As each soil layer was added, it was sprinkled lightly with water.

After installation of the test organisms and soil, all pots were irrigated by hand so that they all could drain and stabilize at about field capacity. Pots in "tarped" treatments were then covered with clear 1.1-mm-thick polyethylene tarp (Leco Industries, St. Laurent, Quebec) held in place by a heavy rubber strap stretched around the exposed lip of each pot. In all experiments, probes were installed at 5,15 , and $30 \mathrm{~cm}$ so that soil temperatures could be recorded at 10-min intervals with microloggers (Onset Computer Corporation, Pocasset, MA).

Fumigant application. At each geographical location, each chemical treatment was applied immediately after the placement of sachets in pot. The experimental design was a complete randomized block with four replications. The same treatments were applied at all three sites, and the experiments were repeated over 2 years. The treatments included 28, 56, 84, 112, and $168 \mathrm{~kg} \cdot \mathrm{ha}^{-1}$ propargyl bromide (90\%; Albemarle Corp.,

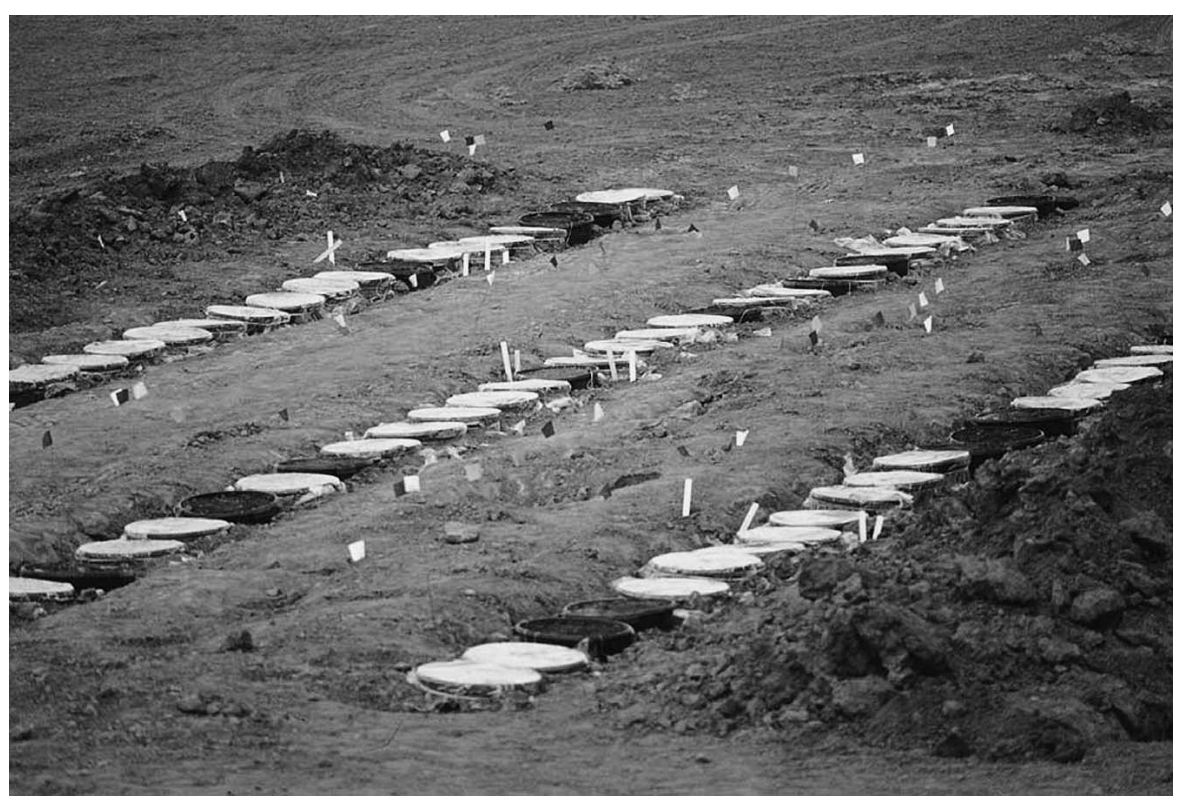

Fig. 1. Experimental setup of container experiments testing the efficacy of propargyl bromide and other soil fumigants against soil-borne pests. 
Baton Rouge, LA), $364 \mathrm{~kg} \cdot \mathrm{ha}^{-1}$ MBC (87\%/ 33\%; Dow AgroSciences, Indianapolis), 168 and $263 \mathrm{~kg} \cdot \mathrm{ha}^{-1}$ iodomethane $(100 \%$; Arvesta Corp., San Francisco), and $358 \mathrm{~kg} \cdot \mathrm{ha}^{-1}$ metam sodium (Amvac, Los Angeles). Tarped and "untarped" untreated controls were included.

Methyl bromide/chloropicrin was applied to a depth of $30 \mathrm{~cm}$ through the plastic from a pressurized cylinder. Propargyl bromide and iodomethane also were applied through the plastic to a depth of $30 \mathrm{~cm}$ using a gas-tight syringe with a stainless steel needle. Tape was applied to close the holes created in the plastic tarps by fumigant injection. In 2000, metam sodium was applied using a syringe and was injected from the surface into a 0.95 $\mathrm{cm}$ hole that extended down to the $30-\mathrm{cm}$ depth. In 2001, one-third of the metam sodium dosage was applied at each of the 30-, 15-, and 5-cm depths, with different injection holes for each depth. Treated pots were left covered for $7 \mathrm{~d}$, after which the plastic was removed. Pots were allowed to ventilate for $1 \mathrm{~d}$ before removal of the sachets. All retrieved sachets were immediately placed in an insulated plastic cooler and transported to the laboratory for analysis.

Statistical analyses. The percent reduction in the number of viable citrus nematodes was determined by comparing viable survivors with the number of viable nematodes recoverable from sachets before burial. The percent reduction in viable Fusarium propagules was expressed as a percentage of the numbers recovered from treated plots relative to the numbers recovered from the untarped, untreated controls. The percent reduction in viable weed seeds was determined by counting the numbers of seeds (out of 100) that failed to germinate or that tested negative for viability. Differences in pest survival among amendment treatments were determined by a ranked analysis of variance, and means were separated by Tukey's adjustment for multiple comparisons $(P<0.05)$. Data were log transformed, when appropriate, to meet the assumptions of normality and homogeneity of variance (SAS, Cary, NC).

\section{Results}

While carrying out these experiments, we found that the survival results from the $5-\mathrm{cm}$ depth could not be used reliably to compare fumigant treatments. This was because at all sites, the tarping treatment alone caused soil temperatures to increase, leading to confounding thermal effects. At the 5-cm depth, tarped treatments had soil temperatures that generally were $10{ }^{\circ} \mathrm{C}$ hotter than untarped treatments (Table 1). At $15 \mathrm{~cm}$, this difference was about halved, and at $30 \mathrm{~cm}$ there was only a 0 to $2{ }^{\circ} \mathrm{C}$ difference. As a result, citrus nematode populations were reduced by more than $91 \%$ at the $5-\mathrm{cm}$ depth at all sites during both years. Likewise, $F$. oxysporum survival was always less in the tarped versus untarped controls. Although less pronounced at $15 \mathrm{~cm}$, there still was some tarping effect, at least at Davis during 2001, where climatic conditions led to the highest soil temperatures (Table 1). This tarping effect led to a $54 \%$ greater reduction in citrus nematode survival and a $33 \%$ greater reduction in Fusarium survival at $15 \mathrm{~cm}$ compared with the untarped treatment. There was no independent influence of tarping at 15 or $30 \mathrm{~cm}$ at any of the other sites. For this reason, only data from the $15-$ and $30-\mathrm{cm}$ depths are presented.

Nematodes. The populations of viable citrus nematodes were reduced $100 \%$ by virtually all fumigant treatments at all sites during both years. The only exception was at Watsonville during 2000 (Table 2), where there was no nematode reduction at $30 \mathrm{~cm}$ with $368 \mathrm{~kg} \cdot \mathrm{ha}^{-1}$ metam sodium. The lack of control at $30 \mathrm{~cm}$, with complete control at $15 \mathrm{~cm}$, suggests some sort of experimental error in this datum point.

Fusarium. At the Davis and MBA sites during both years, Fusarium populations were reduced more than $98 \%$ and $83 \%$ respectively for all fumigant treatments at all depths $(P>0.1)$. At Watsonville, results were more variable, although not significantly so (Table 2). During both years at $15 \mathrm{~cm}$, Fusarium reduction was slightly less with the two lowest rates of propargyl bromide (28 and $56 \mathrm{~kg} \cdot \mathrm{ha}^{-1}$ ). This effect was not

observed at $30 \mathrm{~cm}$. Also, as observed for the citrus nematode at Watsonville during 2000, there was no reduction of Fusarium in the $358 \mathrm{~kg} \cdot \mathrm{ha}^{-1}, 30-\mathrm{cm}$ metam sodium treatment (Table 2).

Weeds. In contrast to the citrus nematode and Fusarium, the weed species varied greatly in their susceptibility to propargyl bromide (Fig. 2). These differences were observed both years at all locations and were similar at 15 and $30 \mathrm{~cm}$; therefore, data from $15 \mathrm{~cm}$ are presented.

Comparing all propargyl bromide treatments at the $15-\mathrm{cm}$ depth (Fig. 2) shows that good annual bluegrass control was achieved in all trials at treatment rates at or more than $56 \mathrm{~kg} \cdot \mathrm{ha}^{-1}$, with the exception of MBA in 2001. The reason for the extreme divergence in the data between 2000 and 2001 at MBA is unknown, but a strong divergence was also noted in the response of field bindweed at MBA (Fig. 2). There was a significant dose response of annual bluegrass to propargyl bromide in both years, with only the three highest treatment doses consistently yielding results that were not significantly different from MBC (Table 3). At Watsonville there was a significant dose response of annual bluegrass to iodomethane in both 2000 (Table 3) and 2001, where only the highest

Table 1. Maximum soil temperatures during fumigation experiments in three California soils.

\begin{tabular}{llccc}
\hline & & \multicolumn{3}{c}{ Temperature $\left({ }^{\circ} \mathrm{C}\right)^{\mathrm{z}}$} \\
\cline { 3 - 5 } Location & Treatment & $\begin{array}{c}\text { Soil depth, } \\
5 \mathrm{~cm}\end{array}$ & $\begin{array}{c}\text { Soil depth, } \\
15 \mathrm{~cm}\end{array}$ & $\begin{array}{c}\text { Soil depth, } \\
30 \mathrm{~cm}\end{array}$ \\
\hline Davis 2000 & Untarped & $\mathrm{NT}^{\mathrm{y}}$ & 35 & 33 \\
Monterey Bay Academy 2000 & Tarped & 49 & 32 \\
& Untarped & 34 & 33 & 29 \\
Watsonville 2000 & Tarped & 44 & 36 & 30 \\
Davis 2001 & Untarped & 38 & 34 & 24 \\
& Tarped & 47 & 40 & 30 \\
Monterey Bay Academy 2001 & Untarped & 44 & 35 & 32 \\
Watsonville 2001 & Tarped & 53 & 42 & 28 \\
& Untarped & 37 & 34 & 30 \\
& Tarped & 45 & 30 & 26 \\
\hline
\end{tabular}

${ }^{\mathrm{z}}$ Measured at 10-min intervals by Onset Stowaway microloggers.

yot tested.

${ }^{\mathrm{x}}$ Six-day tarping period.

Table 2. Percent citrus nematode (Tylenchulus semipenetrans) and Fusarium spp. reduction ${ }^{\mathrm{z}}$ during 2 years at Watsonville, CA.

\begin{tabular}{|c|c|c|c|c|c|c|c|c|}
\hline \multirow[b]{3}{*}{ Treatment } & \multicolumn{4}{|c|}{ Citrus Nematode } & \multicolumn{4}{|c|}{ Fusarium spp. } \\
\hline & \multicolumn{2}{|c|}{2000} & \multicolumn{2}{|c|}{2001} & \multicolumn{2}{|c|}{2000} & \multicolumn{2}{|c|}{2001} \\
\hline & $15 \mathrm{~cm}$ & $30 \mathrm{~cm}$ & $15 \mathrm{~cm}$ & $30 \mathrm{~cm}$ & $15 \mathrm{~cm}$ & $30 \mathrm{~cm}$ & $15 \mathrm{~cm}$ & $30 \mathrm{~cm}$ \\
\hline Untarped & $3 \mathrm{a}^{\mathrm{y}}$ & $0 \mathrm{a}$ & $28 \mathrm{a}$ & $0 \mathrm{a}$ & $0 \mathrm{a}$ & $0 \mathrm{a}$ & $3 a$ & $1 \mathrm{a}$ \\
\hline Tarped & $0 \mathrm{a}$ & $6 \mathrm{a}$ & $59 \mathrm{a}$ & $18 \mathrm{a}$ & $0 \mathrm{a}$ & $35 \mathrm{a}$ & $29 \mathrm{a}$ & $19 \mathrm{a}$ \\
\hline Propargyl bromide $28 \mathrm{~kg} \cdot \mathrm{ha}^{-1}$ & $100 \mathrm{~b}$ & $100 \mathrm{~b}$ & $100 \mathrm{~b}$ & $100 \mathrm{~b}$ & $83 \mathrm{~b}$ & $100 \mathrm{~b}$ & $74 \mathrm{~b}$ & $100 \mathrm{~b}$ \\
\hline Propargyl bromide $56 \mathrm{~kg} \cdot \mathrm{ha}^{-1}$ & $100 \mathrm{~b}$ & $100 \mathrm{~b}$ & $100 \mathrm{~b}$ & $100 \mathrm{~b}$ & $95 \mathrm{~b}$ & $100 \mathrm{~b}$ & $89 \mathrm{~b}$ & $100 \mathrm{~b}$ \\
\hline Propargyl bromide $84 \mathrm{~kg} \cdot \mathrm{ha}^{-1}$ & $100 \mathrm{~b}$ & $100 \mathrm{~b}$ & $100 \mathrm{~b}$ & $100 \mathrm{~b}$ & $100 \mathrm{~b}$ & $100 \mathrm{~b}$ & $100 \mathrm{~b}$ & $100 \mathrm{~b}$ \\
\hline Propargyl bromide $112 \mathrm{~kg} \cdot \mathrm{ha}^{-1}$ & $100 \mathrm{~b}$ & $100 \mathrm{~b}$ & $100 \mathrm{~b}$ & $100 \mathrm{~b}$ & $100 \mathrm{~b}$ & $100 \mathrm{~b}$ & $91 \mathrm{~b}$ & 100 \\
\hline Propargyl bromide $168 \mathrm{~kg} \cdot \mathrm{ha}^{-1}$ & $100 \mathrm{~b}$ & $100 \mathrm{~b}$ & $100 \mathrm{~b}$ & $100 \mathrm{~b}$ & $100 \mathrm{~b}$ & $100 \mathrm{~b}$ & $100 \mathrm{~b}$ & $100 \mathrm{~b}$ \\
\hline Iodomethane $168 \mathrm{~kg} \cdot \mathrm{ha}^{-1}$ & $100 \mathrm{~b}$ & $100 \mathrm{~b}$ & $100 \mathrm{~b}$ & $100 \mathrm{~b}$ & $99 \mathrm{~b}$ & $91 \mathrm{~b}$ & $81 \mathrm{~b}$ & $79 \mathrm{~b}$ \\
\hline Iodomethane $263 \mathrm{~kg} \cdot \mathrm{ha}^{-1}$ & $100 \mathrm{~b}$ & $100 \mathrm{~b}$ & $100 \mathrm{~b}$ & $100 \mathrm{~b}$ & $100 \mathrm{~b}$ & $100 \mathrm{~b}$ & $96 \mathrm{~b}$ & $95 \mathrm{~b}$ \\
\hline $\mathrm{MBC}^{\mathrm{x}} 364 \mathrm{~kg} \cdot \mathrm{ha}^{-1}$ & $100 \mathrm{~b}$ & $100 \mathrm{~b}$ & $100 \mathrm{~b}$ & $100 \mathrm{~b}$ & $100 \mathrm{~b}$ & $100 \mathrm{~b}$ & $100 \mathrm{~b}$ & $100 \mathrm{~b}$ \\
\hline Metam sodium $358 \mathrm{~kg} \cdot \mathrm{ha}^{-1}$ & $100 \mathrm{~b}$ & $0 \mathrm{a}$ & $100 \mathrm{~b}$ & $100 \mathrm{~b}$ & $94 \mathrm{~b}$ & $0 \mathrm{a}$ & $100 \mathrm{~b}$ & $82 \mathrm{~b}$ \\
\hline
\end{tabular}

zercent reduction is related to the untarped control.

${ }^{y}$ Means followed by the same letter within a column are not significantly different according to Tukey's adjustment for multiple comparisons $(P<0.001)$.

${ }^{x}$ Methyl bromide/chloropicrin $(87 \% / 33 \%)$. 
rate of iodomethane $\left(263 \mathrm{~kg} \cdot \mathrm{ha}^{-1}\right)$ yielded reductions in seed viability that were not significantly different from MBC.

Pigweed seed viability was reduced with increasing rates of propargyl bromide, but the exact dose response varied between 2000 and 2001 (Fig. 2). In 2000, there was a more than $85 \%$ reduction in pigweed viability at the lowest rate of propargyl bromide at all sites, and $100 \%$ reduction at higher rates. In 2001, rates three times higher were required for the same result. At Watsonville during 2000, pigweed germination was reduced by more than $87 \%$ at all depths by all fumigants (Table $3)$. Only metam sodium at $30 \mathrm{~cm}$ differed from the other fumigant treatments, similar to that observed for the citrus nematode and

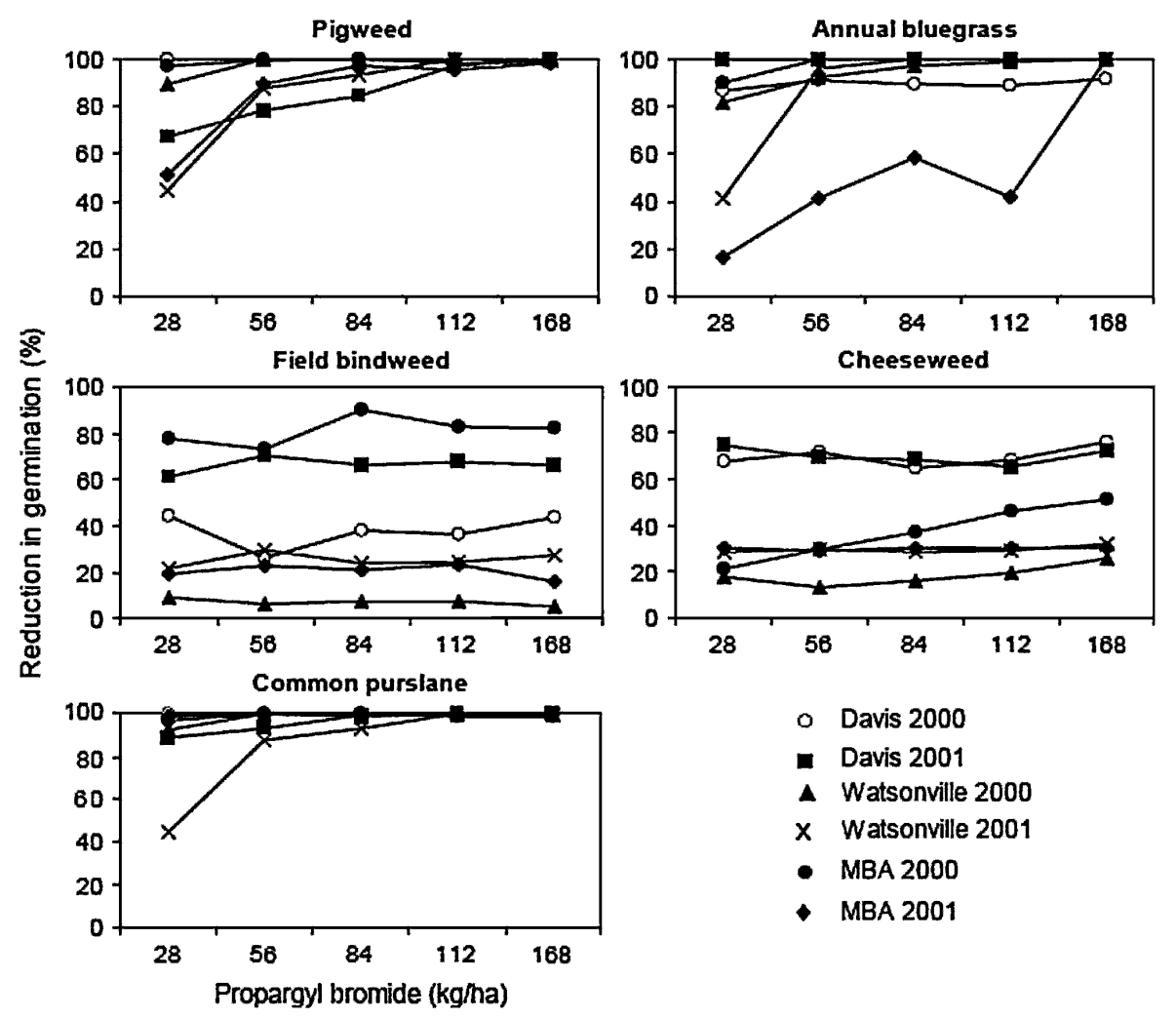

Fig. 2. Percent weed species reduction (percentage of seed not germinating out of an initial 100 seeds) across a range of propargyl bromide application rates at Monterey Bay Academy (MBA), Watsonville, and Davis, CA, during 2 years. Each value is the average of four replications.
Fusarium (Table 2). Results were similar at the other two sites, with more than $78 \%$ and $84 \%$ reductions in pigweed by the other soil fumigants at MBA and Davis respectively.

A significant $(P<0.01)$ dose response to propargyl bromide by common purslane was only observed at Watsonville during 2001 (Fig. 2). At all sites during both years there was $100 \%$ reduction in common purslane germination with rates at or more than 112 $\mathrm{kg} \cdot \mathrm{ha}^{-1}$ propargyl bromide. At Watsonville during 2000, fumigant treatments were not different from each other (Table 3 ). In general, similar results were observed at the other sites during both years, with more than $80 \%$ reduction in common purslane germination. An exception was metam sodium, bromide and the other fumigants for field bindweed control. At Watsonville during 2000 (Table 3) and 2001, MBA during 2001, and Davis during 2000, there was never more than a $52 \%$ reduction of field bindweed seed viability by any fumigant. During 2000 at MBA and 2001 at Davis, the maximum reduction in field bindweed seed viability by any fumigant ranged from $49 \%$ to $90 \%$ regardless of depth. In most cases, fumigant treatments were not consistently different from the controls at any site or depth for field bindweed control (data not shown).

\section{Discussion}

These experiments showed that soil-borne pests varied greatly in their susceptibility to propargyl bromide. Although propargyl bromide at relatively low dosages proved highly efficacious against the citrus nematode and $F$. oxysporum, and very efficacious against pigweed, annual bluegrass, and common purslane, it was relatively ineffective against field bindweed and cheeseweed. These results for propargyl bromide are not unique, because weeds are generally considered more resistant to fumigants than plant-parasitic nematodes or fungi (Ohr et al., 1996). Also, only $F$. oxysporum was used as a fungal test organism, even though fungal species are known to vary in sensitivity to fumigants

Table 3. Percent weed reduction after fumigant treatment at Watsonville, CA during $2000^{z}$.

\begin{tabular}{|c|c|c|c|c|c|c|c|c|c|c|}
\hline Treatment & \multicolumn{2}{|c|}{$\begin{array}{c}\text { Annual } \\
\text { bluegrass }\end{array}$} & \multicolumn{2}{|c|}{ Pigweed } & \multicolumn{2}{|c|}{ Cheeseweed ${ }^{y}$} & \multicolumn{2}{|c|}{$\begin{array}{c}\text { Field } \\
\text { bindweed }^{y}\end{array}$} & \multicolumn{2}{|c|}{$\begin{array}{l}\text { Common } \\
\text { purslane }\end{array}$} \\
\hline Untarped & $3 \mathrm{a}^{\mathrm{x}}$ & $3 \mathrm{a}$ & $10 \mathrm{a}$ & $3 \mathrm{a}$ & 25 & 20 & 14 & 20 & $6 a$ & $4 \mathrm{a}$ \\
\hline Propargyl bromide $56 \mathrm{~kg} \cdot \mathrm{ha}^{-1}$ & $93 \mathrm{bc}$ & $86 \mathrm{bc}$ & $100 \mathrm{~b}$ & $99 \mathrm{c}$ & 13 & 19 & 6 & 2 & $100 \mathrm{~b}$ & $98 \mathrm{~b}$ \\
\hline Propargyl bromide $84 \mathrm{~kg} \cdot \mathrm{ha}^{-1}$ & $97 \mathrm{c}$ & 94 cdef & $100 \mathrm{~b}$ & $100 \mathrm{c}$ & 16 & 22 & 7 & 4 & $99 \mathrm{~b}$ & $100 \mathrm{~b}$ \\
\hline Propargyl bromide $112 \mathrm{~kg} / \mathrm{ha}$ & $99 \mathrm{~cd}$ & 97 def & $100 \mathrm{~b}$ & $100 \mathrm{c}$ & 20 & 14 & 7 & 5 & $100 \mathrm{~b}$ & $100 \mathrm{~b}$ \\
\hline Iodomethane $263 \mathrm{~kg} \cdot \mathrm{ha}^{-1}$ & $99 \mathrm{~d}$ & $100 \mathrm{f}$ & $100 \mathrm{~b}$ & $100 \mathrm{c}$ & 33 & 18 & 7 & 5 & $100 \mathrm{~b}$ & $100 \mathrm{~b}$ \\
\hline $\mathrm{MBC}^{\mathrm{w}} 364 \mathrm{~kg} \cdot \mathrm{ha}^{-1}$ & $99 \mathrm{~cd}$ & 99 ef & $100 \mathrm{~b}$ & $99 \mathrm{c}$ & 17 & 16 & 9 & 3 & $100 \mathrm{~b}$ & $100 \mathrm{~b}$ \\
\hline Metam sodium $358 \mathrm{~kg} \cdot \mathrm{ha}^{-1}$ & $90 \mathrm{bc}$ & $88 \mathrm{bcd}$ & $92 \mathrm{~b}$ & $87 \mathrm{~b}$ & 18 & 18 & 13 & 12 & $93 \mathrm{~b}$ & $90 \mathrm{~b}$ \\
\hline
\end{tabular}

${ }^{2}$ Reduction is the percentage not germinating out of 100 seed. Similar results were observed at Watsonville during 2001.

${ }^{y}$ No significant difference $(P>0.05)$ between treatments for these weed species.

${ }^{\mathrm{x}}$ Means followed by the same letter within a column are not significantly different according to Tukey's adjustment for multiple comparisons $(P<0.001)$.

${ }^{\mathrm{w}}$ Methyl bromide/chloropicrin (87\%/33\%). 
such as iodomethane and methyl bromide (Hutchinson et al., 2000a).

A notable aspect of this research was that it tested propargyl bromide in a nonlaboratory environment, whereas most previous research has emphasized laboratory experiments. For example, laboratory studies determined that the concentration of propargyl bromide needed to kill $50 \%\left(\mathrm{LC}_{50}\right)$ of a population of barnyardgrass [Echinochloa crus-galli (L.) Brauv] was about four times lower than that for $F$. oxysporum (Ma et al., 2001). The estimated propargyl bromide concentration needed to kill $90 \%\left(\mathrm{LC}_{90}\right)$ of a barnyardgrass population was $10 \mathrm{~kg} \cdot \mathrm{ha}^{-1}$. Although we did not test barnyardgrass, we found that propargyl bromide did not effectively control weeds at the rates less than $56 \mathrm{~kg} \cdot \mathrm{ha}^{-1}$, and results were more consistent at rates of $112 \mathrm{~kg} \cdot \mathrm{ha}^{-1}$ and above. We also found that field bindweed and cheeseweed were not completely controlled even at the highest rate of propargyl bromide: $168 \mathrm{~kg} \cdot \mathrm{ha}^{-1}$. In another laboratory study, the relative order of sensitivity of soil-borne organisms to propargyl bromide demonstrated that the citrus nematode was the most sensitive, followed by barnyardgrass then $F$. oxysporum (Allaire et al., 2005). In our field study, citrus nematode and $F$. oxysporum were always more sensitive to propargyl bromide compared with the weed species tested. $\mathrm{Ma}$ et al. (2001) reported an $\mathrm{LC}_{90}$ value of 50 $\mathrm{kg} \cdot \mathrm{ha}^{-1}$ to control $F$. oxyspoum in loamy sand and sandy loam soils. However, in our experiments, the rate of propargyl bromide required to reduce $F$. oxysporum survival by more than $80 \%$, regardless of soil type, was $28 \mathrm{~kg} \cdot \mathrm{ha}^{-1}$.

Soil physical and chemical properties, as well as moisture and temperature, can play a significant role in determining the fate of soil fumigants by influencing the rate of fumigant diffusion as well as abiotic and biological degradation processes (Gan et al., 1994; Zhang et al., 1998). Considerable research has been conducted regarding the environmental and physical factors that may influence the efficacy of propargyl bromide as a soil fumigant (Ma et al., 2001; Papiernik and Yates, 2002; Papiernik et al., 2000; Wang et al., 1999; Yates and Gan, 1998). Although we found no consistent difference in propargyl bromide efficacy between the geographical locations of this study, it has been shown that propargyl bromide is 20 times less effective in an organic matter-rich muck soil than in a sandy loam or loamy sand (Ma et al., 2001).

Probably the biggest environmental factor that distinguished our locations was soil temperature. Soil solarization is known to be an effective pest management strategy (Elmore, 1991). The sustained soil temperatures of more than $37{ }^{\circ} \mathrm{C}$ at our 5-cm depths were sufficient to result in nematode and fungal mortality. Although elevated temperatures were achieved at $15 \mathrm{~cm}$, they were not sustained for as long a period compared with the shallower depth. Soil temperature can also influence fumigant performance. Increasing temperature during fumigation increased the efficacy of iodomethane and methyl bromide (Zhang et al., 1998). We did not observe a consistent influence of temperature on the performance of propargyl bromide at any depth.

Methyl bromide and iodomethane efficacy also are influenced by soil moisture (Zhang et al., 1998), with efficacy of both fumigants being greatest in soil having a $14 \%$ moisture content. The moisture of our soils, during both years, ranged from $10 \%$ to $13 \%$. Because propargyl bromide is structurally similar to iodomethane and methyl bromide (Papiernik et al., 2000), the soil moisture achieved in our container trials was adequate to promote diffusion of all fumigants tested.

Propargyl bromide is structurally similar to methyl bromide and iodomethane, but propargyl bromide and iodomethane have lower ozone-depleting potential (Papiernik et al., 2000). Few comparisons have been made in a field setting between propargyl bromide and standard soil fumigants. Shankinjected or drip-applied propargyl bromide, at a rate much higher than those used in this study $\left(>207 \mathrm{~kg} \cdot \mathrm{ha}^{-1}\right)$ provided control of plant-parasitic nematodes throughout the first growing season similar to control achieved with methyl bromide $\left(507 \mathrm{~kg} \cdot \mathrm{ha}^{-1}\right)$ (Schneider et al., 2006). In laboratory experiments propargyl bromide controlled yellow nutsedge (Cyperus esculentus L.) equal to or better than methyl bromide (Hutchinson, 2000; Hutchinson et al., 2000b). However, when propargyl bromide was applied in the field for nutsedge control there was poor or no control compared with methyl bromide. Lack of control was attributed to inadequate knowledge regarding application technology (Hutchinson, 2000). This result also may have been the result of propargyl bromide formulation. In our study, propargyl bromide performed differently between 2000 and 2001. In 2000, a toluene (20\%) formulation of propargyl bromide was used. However, in 2001 a different formulation was used in which the stabilizers were expected to be biologically inert. In general, the 2001 formulation was less effective at controlling weeds at the lower rates. It is possible that toluene in the 2000 formulation played a role in propargyl bromide toxicity to weed seeds.

We found that the degree of control of the citrus nematode and $F$. oxysporum at a propargyl bromide rate of $28 \mathrm{~kg} \cdot \mathrm{ha}^{-1}$ was comparable with standard soil fumigants. Although there were significant differences in weed control between propargyl bromide and the other fumigants at some sites during some years, these differences were not consistent. In general, to achieve control of annual bluegrass, pigweed, and common purslane comparable with the other fumigants, propargyl bromide had to be applied at $\geq 112$ $\mathrm{kg} \cdot \mathrm{ha}^{-1}$. It is important to note, however, that although higher rates of propargyl bromide were required, the rates still were half that required of the other standard fumigants. Cheeseweed and field bindweed proved to be difficult to control with propargyl bromide and the other tested soil fumigants.
These experiments showed that propargyl bromide was an effective fumigant in comparison with other soil fumigants. However, larger scale tests are needed. Unfortunately, until the handling characteristics of this product can be improved, it is unlikely that this compound will be pursued for registration.

\section{Literature Cited}

Allaire, S.E., S.R. Yates, P. Zhang, and F.F. Ernst. 2005. The potential efficiency of irrigation management and propargyl bromide in controlling three soil pests: Tylenchulus semipenetrans, Fusarium oxysporum and Echinochloa crus-galli. Pest Mgt. Sci. 61:799-808.

Elmore, C.L. 1991. Weed control by solarization, p. 61-72. In: J. Kattan and J.E. DeVay (eds.). Soil solarization. CRC Press, Boca Raton, FL.

Gan, J., S.R. Yates, M.A. Anderson, W.F. Spencer, F.F. Ernst, and M.V. Yates. 1994. Effect of soil properties on degradation and sorption on methyl bromide in soil. Chemosphere 29:2685-2700.

Hutchinson, C.M. 2000. Weed control in minor crops after the loss of methyl bromide. HortScience 35:519.

Hutchinson, C.M., M.E. McGiffen Jr., H.D. Ohr, J.J. Sims, and J.O. Becker. 2000a. Efficacy of methyl iodide and synergy with chloropicrin for control of fungi. Pest Mgt. Sci. 56:413-418.

Hutchinson, C.M., M. McGiffen, J. Sims, and J.O. Becker. 2000b. Synergism of fumigant combinations for nutsedge control. HortScience 35:393.

Ingham, R.E. 1994. Nematodes, p. 459-490. In: Methods of soil analysis, part 2. Microbiological and biochemical properties. Soil Society of America book series, no. 5, Madison, WI.

Komada, H. 1975. Development of a selective medium for quantitative isolation of Fusarium oxysporum from natural soil. Rev. Plant Prot. Res. 8:114-124.

Ma, Q., J. Gan, J.O. Becker, S.K. Papiernik, and S.R. Yates. 2001. Evaluation of propargyl bromide for control of barnyardgrass and Fusarium oxysporum in three soils. Pest Mgt. Sci. 57:781-786.

Ohr, H.D., J.J. Sims, N.M. Grech, J.O. Becker, and M.E. McGiffen Jr. 1996. Methyl iodide, an ozone-safe alternative to methyl bromide as a soil fumigant. Plant Dis. 80:731-735.

Papiernik, S.K., J. Gan, and S.R. Yates. 2000 Mechanism of degradation of methyl bromide and propargyl bromide in soil. J. Environ. Qual. 29:1322-1328.

Papiernik, S.K. and S.R. Yates. 2002. Effect of environmental conditions on the permeability of high density polyethylene film to fumigant vapors. Environ. Sci. Technol. 36:1833-1838.

Schneider, S.M., H. Ajwa, and T.J. Trout. 2006. Chemical alternatives to methyl bromide for nematode control under vineyard replant conditions. Amer. J. Enol. Vitic. 57:183-193.

Wang, D., S.R. Yates, J. Gan, and J.A. Knuteson. 1999. Atmospheric volatilization of methyl bromide, 1,3-dichloropropene, and propargyl bromide through two plastic films: Transfer coefficient and temperature effect. Atmosph. Environ. 33:401-407.

Yates, S.R. and J. Gan. 1998. Volatility, adsorption, and degradation of propargyl bromide as a soil fumigant. J. Agr. Food Chem. 46:755761

Zhang, W., M.E. McGiffen Jr., J.O. Becker, H.D. Ohr, J.J. Sims, and S.D. Campbell. 1998. Effect of soil physical factors on methyl iodide and methyl bromide. Pestic. Sci. 53:71-79. 